\title{
Manganese pollution of drinking water extracted from the terrace of Vacha River
}

\section{Замърсяване с манган на добиваните за пиене подземни води от терасата на р. Въча}

\author{
Aleksey Benderev ${ }^{1}$, Nikolay Stoyanov ${ }^{2}$, Stefan Dimovski ${ }^{2}$, Svetlana Bratkova ${ }^{2}$, Boyka Mihaylova ${ }^{1}$ \\ Алексей Бендерев ${ }^{1}$ Николай Стоянов ${ }^{2}$, Стефан Димовски ${ }^{2}$, Светлана Браткова ${ }^{2}$, \\ Бойка Михайлова ${ }^{1}$
}

\author{
${ }^{1}$ Geological Institute, BAS, Acad. G. Bonchev str., bl. 24, Sofia; E-mails: alekseybenderev@yahoo.com; boyka_m@abv.bg \\ ${ }^{2}$ Faculty of Geology and Exploration, University of Mining and Geology "St. Ivan Rilski”, 1700 Sofia, Bulgaria; \\ E-mails: nts@mgu.bg; dimovski@mgu.bg; s_bratkova@mgu.bg
}

\begin{abstract}
The presented study is aimed towards determining the reasons for manganese pollution of drinking water extracted from the terrace of Vacha River. The results show that this is due to the seepage of from the artificial lake, formed after the construction of a small hydropower plant. Another possible reason is the natural accumulation in the upper parts of the river terrace of poorly soluble in water manganese compounds that turn into soluble ones as a result of changes in the redox environment, which take place in the conditions of very intensive groundwater extraction.
\end{abstract}

Keywords: manganese pollution, groundwater-surface water interaction, alluvial deposits, Vacha River.

\section{Introduction}

Groundwater is an important source of water intended for drinking and household purposes not only in Bulgaria but also worldwide. One of the main problems is to guarantee its qualities in order to protect human health against the negative impact of drinking water pollution. The reasons for the elevated concentrations of some components may be of natural origin - interaction of groundwater with various rocks and minerals (Gerginov et al., 2019), or due to the impact of human activities on environment human impact (PeychevaZaharyan, Peytchev, 2008; Palmucci et al., 2016). Manganese (Mn) is commonly found in groundwater and is an essential element required in small amounts by all living organisms, but its presence above certain thresholds makes the waters dangerous to human health and inappropriate for a number of industries. Elevated concentrations of Mn are usually found in the aquifers formed in contemporary river terraces, especially in areas of active groundwater extraction. The study of this problem excites hydrogeologists for several decades. Their efforts are aimed at clarifying the genesis of $\mathrm{Mn}$, the processes influencing subsurface geochemistry and manganese oxidation states, the factors and mechanisms for the mobilization of manganese as $\mathrm{Mn}^{2+}$ into groundwater and the possibilities for its removal within the aquifer (Pentchev et al., 1989; Peycheva-Zaharyan, Peytchev, 2008; Palmucci et al., 2016; McMahon et al., 2019).

These topics are also considered by our team in the conducted study of a problematic area in the Quaternary aquifer, formed in the terrace of Vacha River (Fig. 1), before its confluence with Maritsa River. The challenge arises in the beginning of 2020, when elevated concentrations of $\mathrm{Mn}$ are established in the groundwater extracted in the region that is used as a source of drinking water in the village of Brestovitsa, Plovdiv Region. For a short period, the concentration is increased to values above $1 \mathrm{mg} / \mathrm{L}$ at a permissible limit for drinking water of $0.05 \mathrm{mg} / \mathrm{L}$. The objective of the presented study is to identify the reasons for the elevated manganese concentrations and to recommend the required activities that will ensure the provision of safe drinking water for the local residents.

Two hypotheses are considered. The first hypothesis assumes that poorly soluble in water manganese compounds have been accumulated in the alluvial de- 
posits. Then, under certain conditions, they turn into soluble ones and migrate due to natural groundwater flow. This scenario is typical for some discussed in literature examples of extensive manganese pollution in the contemporary terrace of Maritsa River - in the area of Dimitrovgrad, in the area of the village of Yabalkovo, and others (Pentchev et al., 1989; PeychevaZaharyan, Peytchev, 2008). The second hypothesis presumes that the main reason are the processes of eutrophication in the artificial lake, formed in the old stream bed of Vacha River after the construction in 2015 of a small hydropower plant near the village of Kadievo (Fig. 1).

\section{Materials and methods}

In 1984, four pumping wells are installed along Vacha River - W1, W2, W3, and W4 (Fig. 1). The first well provides the drinking water supply for the village of Kadievo, and the others - for the village of Brestovitsa. With their screen sections the wells cover the entire thickness of the Quaternary aquifer. The hydrogeological section is composed of boulders, gravels and sands, interbedded locally with silts and clays. The Quaternary aquifer consists of two water-bearing layers - an upper unconfined aquifer and a lower confined aquifer. They are separated by a clay aquitard having a thickness of 1.5 to $2.6 \mathrm{~m}$. The underlying aquiclude is composed of Neogene clays. The groundwater level of the wells is at a depth of 3.0-3.5 m. The Quaternary aquifer is in direct hydraulic connection with the river and the artificial lake. During the study, the wells operate with a total flow rate of $20-25 \mathrm{~L} / \mathrm{s}$, which guarantees the water supply of the villages of Brestovitsa and Kadievo. There are no data that significant changes have been made in the pumping wells operational regime in the period preceding the increase in the concentration of manganese observed in 2020. Serious changes in the hydrogeological conditions in the problematic area have occurred after the construction of a small hydropower plant near the village of Kadievo, whose gravity dam is $7 \mathrm{~m}$ in height. Gradually, the artificial lake formed in the old stream bed of Vacha River flooded sizeable areas around the river and the wetland stretches to a distance of only 65 $\mathrm{m}$ from the most contaminated pumping well W3. At the same time, the rates of groundwater level rise reach up to 5.5 nearby the gravity dam and up to $1.5 \mathrm{~m}$ in the area of the pumping wells.

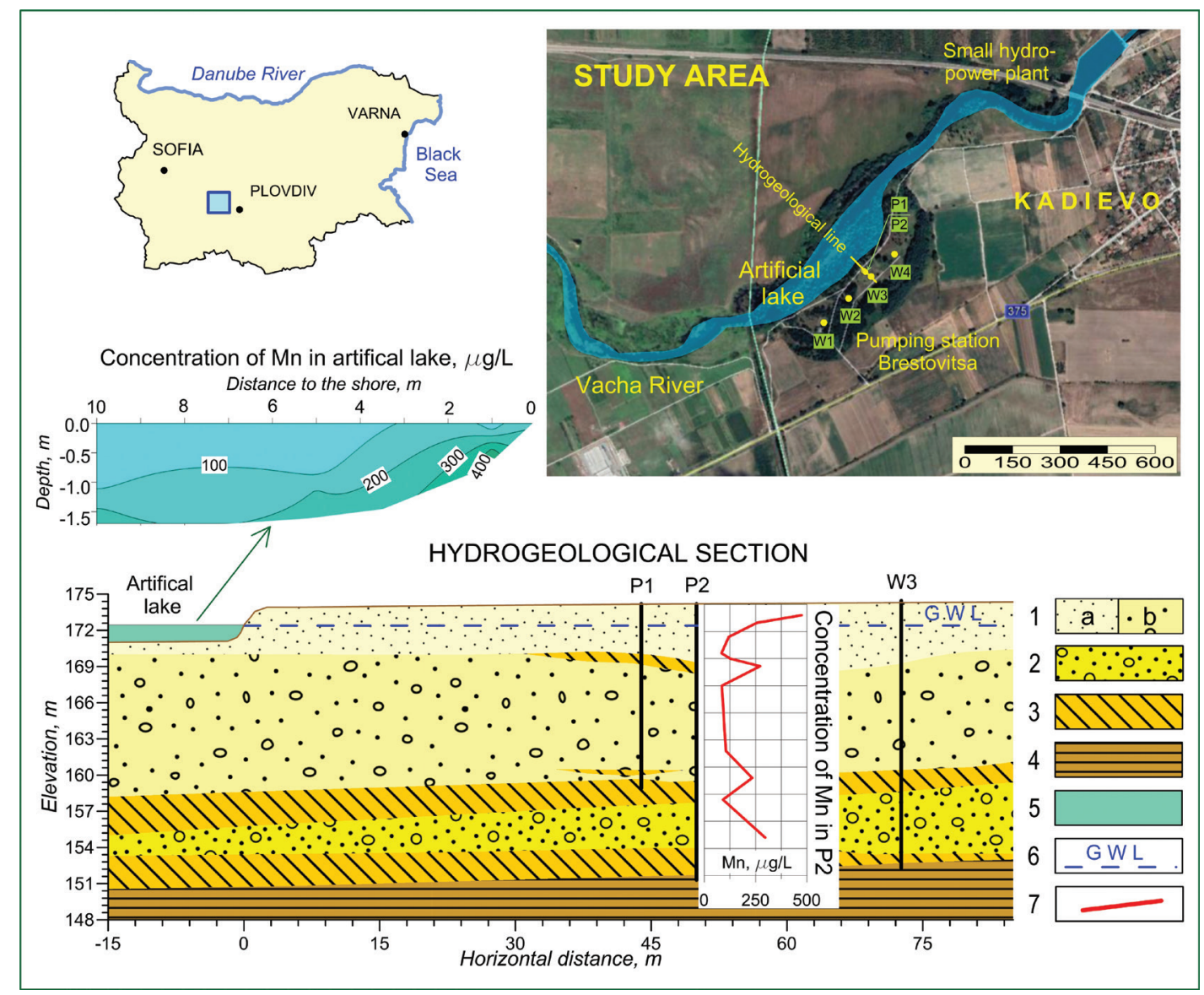

Fig. 1. Location and hydrogeological conditions in the problematic area. 1, upper unconfined aquifer: $a$, Quaternary fine-grained sands, slightly clayey, $b$, Quaternary gravels and boulders with sandy filler; 2, lower confined aquifer - Quaternary gravels and boulders with sandy filler; 3, Quaternary clays, aquitard; 4, Neogene clays, aquiclude; 5, artificial lake; 6, groundwater level; 7, concentration of Mn in observation well P2 by November 2020. 
In order to solve the problem, a complex study is conducted in the hotspot area, including an integrated application of different hydrogeological, drilling, hydrochemical and other research methods. The available data on the geomorphological, hydrological, climatic, geological, hydrogeological, and technogenic conditions in the region are analyzed. A detailed hydrogeological mapping is conducted, including hydrochemical and microbiological study of surface water, groundwater and water for drinking and household purposes. Two observation wells (P1 and P2) are installed in the line between the artificial lake's shore and pumping well W3 (Fig. 1), in which the highest increase in concentration of Mn is observed. Observation well P1 is screened in the upper unconfined aquifer, and observation well P2 with its screen section covers the lower confined aquifer as the upper water-bearing layer is sealed. A detailed description of all drilled lithological types has been made. Pumping tests are performed in observation wells P1 and P2, at the end of which water samples are taken for chemical and microbiological analyses.

\section{Results and discussion}

The collected information and results of the complex study provide an opportunity for better understanding of the source and mobilization mechanisms of Mn and the reasons for the elevation of its concentration in the pumping wells.

As of November 2020, the concentration of Mn in groundwater, beyond the range of impact of the artificial lake, is within the background levels - between 10 and $35 \mu \mathrm{g} / \mathrm{L}$, while in the pumping wells located close to the lake (W2, W3, and W4) it is excessively higher than the background, and in the nearest well (W3) reaches $6499 \mu \mathrm{g} / \mathrm{L}$. Divalent manganese is predominant $-87.5 \%$. The calculated saturation indexes (SI) relative to Mn-containing compounds and minerals show that the water from pumping well W3 is highly unsaturated in respect to most of them, i.e. it still has potential to dissolve them.

The registered changes in the chemical composition of the extracted waters at the beginning, middle and end of the pumping tests performed in observation wells $\mathrm{P} 1$ and $\mathrm{P} 2$ show the following tendencies. The concentration of $\mathrm{Mn}$ in the water extracted from the upper unconfined aquifer rises very quickly to values above $5 \mathrm{mg} / \mathrm{L}$, while in the water extracted from the lower confined aquifer the concentration of manganese decreases by one order of magnitude - from about $0.1 \mathrm{mg} / \mathrm{L}$ to $0.011 \mathrm{mg} / \mathrm{L}$. Obviously, the deeper parts of the Quaternary aquifer are better protected and so far there are no indications that they are contaminated with manganese.

The studied water samples collected at different depths in the artificial lake show that the concentration of $\mathrm{Mn}$ in the near-bottom areas significantly exceeds that in the surface layer (Fig. 1). This pattern is related to changes in the physicochemical conditions in depth. Water in the near-bottom areas is characterized by significantly higher COD (Chemical Oxygen Demand) values (318-461 $\mathrm{mg} \mathrm{O} / 2 \mathrm{dm}^{3}$ ) in comparison to the overlying layers. The sediments rich in organic matter determine the rapid consumption of dissolved $\mathrm{O}_{2}$ by the autochthonous microflora and the creation of reducing conditions favorable for the development of microbial processes such as manganese- and ferrireduction. Data on the decrease of $\mathrm{pH}$ and Eh values, the increase of specific electrical conductance, as well as the established significantly higher concentrations of manganese and iron in near-bottom waters support the hypothesis that manganese pollution is due to microbial reduction of $\mathrm{Mn}^{4+}$ to $\mathrm{Mn}^{2+}$.

\section{Conclusion}

The results of the performed study show that the significant increase in Mn concentration in the pumping wells is due to the seepage of polluted waters from the artificial lake. Another possible reason is the natural accumulation in the upper parts of the river terrace of poorly soluble in water Mn compounds that turn into soluble ones as a result of changes in the redox environment, which take place in the conditions of very intensive groundwater extraction.

Acknowledgement: This work has been carried out in the framework of the National Science Program "Environmental Protection and Reduction of Risks of Adverse Events and Natural Disasters", approved by the Resolution of the Council of Ministers № 577/17.08.2018 and supported by the Ministry of Education and Science (MES) of Bulgaria (Agreement № DO-230/06-12-2018).

\section{References}

Gerginov, P., Th. Kerestedjian, A. Toteva, B. Mihaylova, A. Benderev. 2019. Geological environment, groundwater quality and regulation. - Water Affairs, 5/6, 19-29 (in Bulgarian with English abstract); https://www.stuwa.org/files/magazine/5-6.19_s3.pdf.

McMahon, P., K. Belitz, J. Reddy, T. Johnson. 2019. Elevated manganese concentrations in United States groundwater, role of land surface-soil-aquifer connections. - Environ. Sci. \& Technol., 53, 1, 29-38; https://doi.org/10.1021/acs. est.8b04055.

Palmucci, W., S. Rusi, D. Di Curzio. 2016. Mobilisation processes responsible for iron and manganese contamination of groundwater in Central Adriatic Italy. - Environ. Sci. Pollut. Res., 23, 11790-11805; https://doi.org/10.1007/s11356-0166371-4.

Pentchev, P., N. Stoyanov, V. Vesselinov. 1989. Hydrogeological and mathematical model studies for applying the VIREDOX method. - In: Anniversary Collection 40 years of the Department of Hydrogeology and Engineering Geology, High Mining and Geological Institute (HMGI). Sofia, MES, 51-61 (in Bulgarian with English abstract).

Peycheva-Zaharyan, S., T. Peytchev. 2008. Manganese in ground water: origin, problems and removal. - BULAQUA, 8, 4-14 (in Bulgarian with English abstract); http://www.bd-dunav. org/uploads/content/files/upravlenie-na-vodite/PURB-20162021-final/Razdel-4/Podkr_doc_R4/SD_4GWB1.PDF. 